\title{
Financial Inclusion Strategy and Access to Credit by Micro Small and Medium Scale Enterprise (MSMEs) in Nigeria
}

\author{
Steve N.O. Ibenta \\ Department of Banking and Finance, Nnamdi Azikiwe University, Awka \\ Uju Evans Akpunonu \\ Department of Entrepreneurship Studies, Chukwuemeka Odumegwu Ojukwu University, Igbariam \\ Udoka Bernard Alajekwu* \\ Department of Banking and Finance, Chukwuemeka Odumegwu Ojukwu University, Igbariam
}

\begin{abstract}
Financial inclusion avails all economic units the opportunity to access financial services needed to boost economic activities. One of the objectives of financial inclusion is to provide access to finance for the poor majority who initially do not use formal financial services. The MSMEs requirement for funds is hampered by their limited access to the financial market. This study however investigated the effect of financial inclusion strategies on access to credit by micro, small and medium scale enterprises (MSMEs) in Nigeria. Data for the study were collected from the CBN Statistical bulletin for the period of 1991 to 2019. The explanatory variables used to develop a multiple regression model captured the market capitalization, pension account, insurance account, microfinance account and e-banking as strategies to financial inclusion. The Autoregressive Distributive Lag model was developed and analyzed for long and short-run dynamics of financial inclusion on access to loan and advances by the MSMEs in Nigeria. The bound test showed that financial inclusion strategies had a long-run relationship with loan and advances of the MSMEs. The coefficient of determination explained $99 \%$ of access to loans and advances by the MSMEs in Nigeria. The coefficients of regression revealed that lags of Loan and Advances to MSMEs had adverse endogenous effects on the model. More so, activities in the capital market (MKTC) and pension accounts (PA) at lag 1 have positive and significant effects on credit to MSMEs (LA) in Nigeria; but insurance accounts (IA), microfinance account (MFA) and e-banking innovations (EBDUM) creates unstable significant effects on credit to MSMEs in Nigeria. The study posits that financial inclusion strategies have a long-run impact on MSMEs with the capital market and pension funds the major enhancers of MSME funding.
\end{abstract}

Keywords: Financial inclusion, financial access, micro, small and medium scale enterprises, Nigeria

DOI: $10.7176 / \mathrm{EJBM} / 13-13-06$

Publication date:July $31^{\text {st }} 2021$

\section{Introduction}

It has been observed that in Nigeria, conventional banks and other depository financial institutions generally produce services for the exclusive use of big and well-established companies, individuals and institutions while the poor and low-income populations are held in a permanent vicious cycle of poverty (Ibenta \& Amana, 2010). This financial access wedge against the poor began to shift about three decades ago when certain ingenious and innovative microfinance institutions and their sponsors began to develop financial services with the ultimate purpose of poverty reduction. Many national governments in developing countries adopted various financial inclusion strategies the objective of which is to draw the unbanked population to access formal financial services ranging from savings, payments, and transfers to credits and insurance to promote all-inclusive development and growth of the micro, small and medium scale enterprises (Aduda \& Kadunda, 2016). Microfinance institutions easily spread across the world, in different forms, to deliver formal financial services in a reliable, convenient, affordable, continuous, and flexible manner to those without access to formal financial services.

According to the Central Bank of Nigeria (CBN), the objective of financial inclusion is to draw the unbanked population to assess formal financial services ranging from savings, payments, and transfers to credit and insurance to bring about basic and incremental solutions to the problems of poverty and to promote inclusive development, (CBN, 2019). The CBN and other stakeholders began to implement a National Financial Inclusion Strategy that was intended to reduce the percentage of adult Nigerians that are excluded from financial services from $46.3 \%$ in 2010 to $20 \%$ by 2020 and the number of Nigerians included in the formal sector from $36.3 \%$ in 2010 to $70 \%$ by 2020 , through a broad range of coordinated interventions, with a high priority on the following:

- Transformation of existing Know Your Customer (KYC) regulations into a simplified risk based tiered framework that allows individuals who do not currently meet formal identification requirements to enter the banking system.

- Development and implementation of a Regulatory Framework for Agent Banking to enable financial 
institutions to bring banking services to the unbanked in all parts of the country.

- Development and implementation of a National Financial Literacy Framework to increase awareness and understanding of financial products and services, with the ultimate goal of increasing sustainable usage.

- Implementation of a comprehensive Consumer Protection Framework to safeguard the interest of clients and sustain confidence in the financial sector.

- Continued pursuance of Mobile Payment System and other Cash-less Policies to reduce the cost and increase the ease of financial services and transactions.

- Implementation of Credit Enhancement Schemes/Programmes to empower micro, small, and medium enterprises (MSMEs): Micro, Small and Medium Enterprises Development Fund (MSMEDF), 60\% of which will support loans from microfinance banks and institutions to women and women-owned enterprises; The Nigerian Incentive-Based Risk Sharing System for Agricultural Lending (NIRSAL); Entrepreneurship Development Centres (EDCs); Restructuring and Refinancing Facilities for MSMEs; MSME Credit Guarantee Scheme

Nigeria has also in the past carried out a series of major institutional reforms in its financial sector, specifically in banking, insurance and pensions. The country has also witnessed enormous progress in the area of financial technology such as automated teller machines (ATMs), e-banking, mobile banking, internet banking, agency banking, and mobile phone money transfer services which have transformed the financial landscape in the last decade or so. In particular, mobile phone money transfer services in Nigeria has allowed expansion and access to financial services to previously under-served rural communities by improving access to credit and deposit facilities allowing more efficient allocation of credit, facilitating financial transfers and extending financial services to millions of poor people at relatively low cost which helps to promote economic growth and improve income distribution (Aduda \& Kalunda, 2016).

However, while the use of financial services, measured as having deposits account with banks reach over $90 \%$ in most high-income countries, in many low-income countries, the use of formal financial services is restricted to small numbers of house-holds and firms (Peachey \& Roe, 2004; Demirgure-Kunt \& Beck, 2007). The Constructive Group to Assist the Poor (CGAP), in its Financial Access 2010 report shows that Nigerian microfinance institutions have 34 accounts per 1000 adults, 2.87 branches per 100,000 adults, and loans amounting to $0.17 \%$ of the GDP.

In 2018, the Enhancing Financial Innovation and Access Survey Report shows that actual insurance uptake in Nigeria stood at 2 per cent. There was an increase of 1.4 per cent in the banked population from 2016 to 2018 , a decrease of 2.2 per cent in remittances in the two years and another decrease of 6.7 per cent in savings with banks during the period. The Report also indicated that 71.3 per cent of the 99.6 million adult Nigerians did not have access to mobile money accounts and a mere 17.5 per cent is the borrowing rate among Nigerians. These data show that access to microfinance in Nigeria is still one of the lowest on the continent, and suggests that the high exclusion rate arises from insufficient income and high risk profile or due to discrimination and market failures and imperfections.

On the other hand, there is no conclusive evidence from recent empirical studies on the impact of financial inclusion on financial access by the multitude of micro, small and medium scale enterprises in Nigeria (See for example Ibenta \& Amana, 2010; Mbam, 2012; Nwosa \& Oseni, 2013; Uduakobon, 2014; Owolabi \& Nasiru, 2017; Imoughele \& Ismaila, 2014; Amadasu, 2017; and Abusomwan \& Arodoye, 2017).

In the light of the above, the researchers are interested to determine the effect of financial inclusion strategy on access to credit by MSMEs in Nigeria. Specifically, the study will be guided by the following subsidiary objectives:

1. To determine the influence of market capitalization per head on Micro, Small and Medium Enterprises (MSMEs) credit in Nigeria.

2. To examine the influence of pension accounts per head on Micro, Small and Medium Enterprises (MSMEs) credit in Nigeria.

3. To evaluate the influence of insurance coverage per head on Micro, Small and Medium Enterprises (MSMEs) credit in Nigeria.

To investigate the influence of micro-finance accounts per head on Micro, Small and Medium Enterprises (MSMEs) credit in Nigeria.

To assess the relationship between e-Banking transactions per head and Micro, Small and Medium Enterprises (MSMEs) credit in Nigeria.

\section{Literature Review}

\subsection{Financial Inclusion versus Problem of Access to Finance}

Recent empirical evidence using household data indicates that access to basic financial services such as savings, payments and credit can make a substantial positive difference in improving poor people's lives (Caskey et al., 
2006; Dupas \& Robinson, 2009). For firms, especially the micro, small and medium enterprises (MSMEs), access to finance is often the main obstacle to growth (Schiffer \& Weder, 2001; Cressy, 2002; Beck \& Levine, 2005, 2006, and 2008). According to UK Financial Inclusion Report (2019), an inclusive financial sector is characterized by the density of financial service providers, the level of competition between them and the legal and regulatory environments that ensure the integrity of the financial sector and access to financial services for all. Financial exclusion is a condition where a segment of the population or firms are unable to access formal financial services as a result of insufficient income and high risk or due to discrimination and market failures and imperfections which can be addressed by appropriate economic programs and policies. (World Bank. 2013).

Lack of access or voluntary exclusion to financial services is simply the fact that financial services are not being used. Lack of access may reflect either supply or demand factors; for example, households and firms may be observed not to use credit simply because they may not need to borrow because they lack viable investment projects. An imprudent access to credit, which originated in exuberant or predatory lending that did not appropriately internalize the risk involved in investments, has often led to many financial crises. Hence, some borrowers may be excluded from credit because their project may not be able to generate return large enough to pay back the debt.

Defining the problem of access to finance poses a major problem because financial services are extremely heterogeneous, including all sorts of savings, payments, insurance, and credit, each of which has its own unique costs, risks and production functions. The common problems of access to credit according to De la Torre, Gozzi \& Schmukler (2007):

Exist when a project that would be internally financed if resources were available, does not get external finance due to the presence of a wedge between the expected internal rate of returns of the projects, and the rate of return that external investors require to finance it.

\subsubsection{The Measurement of Access to Credit}

In the household survey by Claessens (2006), the asset measurements used are:

1. Number of households in a community,

2. Number of households that saved money in the past 12 months,

3. Number of households that used financial institutions to save in the past 12 Months

4. Share of households that used informal finance to save,

5. Share of households that borrowed money in the past 12 months,

6. Share of households that used formal financial institutions to borrow,

7. Share of households that used informal financial institutions to borrow.

Financial Access Format designed for microfinance institutions by the Consultative Group to Assist the Poor (CGAP) requires information on deposits, loans and outreach. It provides data on member countries concerning:

i. Account deposits per 1000 adults,

ii. Average account value (\% of income per capita)

iii. Loan outreach per 1000 adults,

iv. Outreach:

a) Branches per 100,000 adults for total population,

b) Branches per 100,000 adults in urban population,

c) Branches per 100,000 adults in rural population

According to the Global Partnership for Financial Inclusion, it can be measured in three dimensions:

i. Access to financial services, that is, depth of outreach of financial services such as penetration of bank branches, Point of Sale (PoS) or devices in rural areas.

ii. Usage of financial services indicators such as average savings, number of transactions per account, number of electronic payments etc

iii. The quality of the products and service delivery.

These indicators measure the range of options available to customers and clients' awareness and understanding of the financial products and services.

\subsubsection{Institutions and Broadening of Access to Finance}

Institutions (public and private) in an economy affect information flows, transactions costs and contract enforcements, and are expected to impact significantly on financial development and access to external finance. Beck and Levine (2005) reviewed literature which provided significant evidence to show that countries with legal systems to enforce property rights, support private contract, protect the rights of creditors and shareholders have more developed financial systems. In countries with weak public institutions, the writing and enforcing of contracts are difficult; also publicly available information is scanty. In such places, agency problems can only be mitigated through arrangements between private parties, relying heavily on personal relationships, fixed (usually real estate) collateral and group lending and monitoring. Sometimes, the threat of violence and physical intimidation and punishment are also commonly used by loan sharks to deal with agency problems in financially underdeveloped markets. 
Institutional development can thus broaden access to finance. The view that financial development is closely related to institutional development implies that in the process of the evolution of any financial institution, it is financial development characterized by what North (1990), refers to as "path dependence". Path dependence reflects the fact that institutional arrangements are self-reinforcing due to substantial increasing returns that arise from economies of scale, the subsequent lowering of costs and the associated spillover and externalities for contracting between parties.

\subsection{Theoretical Framework}

This study is predicated on three main theories: the finance-gap theory, the finance-led growth theory and the principal-agent theory.

\subsubsection{The Finance Gap Theory}

The Organization for Economic Cooperation and Development (OECD, 2006) has postulated a "Financing gap" theory for micro, small and medium enterprises. Theoretically, empirical literature argues that a large segment of those who are financially excluded globally from formal financial services are mainly the low income group and the micro, small and medium enterprises due to lack of capacity and market imperfections. The finance gap therefore refers to the problem faced by small businesses in raising external capital to fund its business operations so as to generate sufficient income to enable them to expand and grow. In Nigeria for example, there is an army of young entrepreneurs, unemployed graduates and other micro, small and medium enterprises with profitable business proposals, who could use funds productively if they were available, but cannot obtain funds from the formal financial markets.

\subsubsection{The Finance-led Growth Theory}

The finance-led growth theory was originated by Bagehot (1873). Theories on the finance growth nexus maintain that financial intermediaries create a productive environment for growth and economic sustainability through supply - leading or demand - following effect. The supply-leading school argues that finance is a prerequisite for any economic activity and that availability and cost of funds for business depends to a large extent on the workings of financial institutions and markets. According to Gordon (1983 cited in Ibenta, 2000):

"They are the means by which savings are mobilized or investments are transferred from low yielding to higher yielding ones; and by which savers and investors diversify risk, as well as the means by which fluctuations in the economy and the resource needs of the firms and the public sector are smoothed out. In other words, they are the key mechanisms for adjustment and lubrication in an increasing complex and dynamic economy"

\subsubsection{Financial Access, Agency Problem and Transaction Costs}

There is a large volume of theoretical and empirical literature which shows the importance of a well-developed financial system for economic development and poverty alleviation (Demirgurc-Kunt \& Levine 2004; Honohan, 2004).The wedge between the expected internal rate of return of a project and the rate of return that external investors require to finance it is introduced by two familiar constraints, which hamper the ability to write and enforce financing contracts; which are principal-agent problems and transaction costs. The canonical analysis of principal-agent problem in finance was developed by Stiglitz and Weiss (1981). They explained the access discrepancy by referring to agency theory. Van Horne and Warchovicz (2005) consider agency theory as a branch of economics which deals with the relationship between principals and agents in an organization. Adverse selection and moral hazard effects are due to information asymmetry between the principal (lender) and the agent (borrowers). In the case of ordinary goods, its price is determined by the interplay of the forces of demand and supply to reach an equilibrium point. If the price is too high for some, they will not use it. So if prices do their work well, there will be no access problem. However, credit markets are different, because information problem can lead to credit rationing even in equilibrium. The reason for this anomaly is that banks making loans (or buying debts) are concerned not only about the interest they charge on the loan but also the riskiness of the loan. At the same time, the interest rate that the bank charges may itself affect the riskiness of the portfolio of loan either by attracting high risk borrowers (adverse selection effect) or by adversely affecting the action and incentives of borrowers (moral hazard effect).

The adverse selection problem arises because high risk borrowers are the ones that are more likely to look for external finance. A banker/financier may be willing to provide financing for some debtors or projects by increasing the risk premium charged, but this approach can backfire at some point due to adverse selection problem. The reason is that as the risk premium required by lenders rises, so does the riskiness. High risk borrowers are "adversely selected" by higher risk premiums. Faced with the adverse selection risk, lenders will try to use non-price criteria to screen debtors and projects, and ration and apportion credit, rather than further increasing the risk premium.

The moral hazard problem refers to the situation after the agent (e.g the debtors) has received the resources from the principal (lender). The problem arises because the agent may have advantaged or classified information 
and decide to use the resources in ways that are not consistent with the interest of the principal. For example, the agent may divert the borrowed resources to riskier activities, strip and loot assets, or run away with the money, while the creditor has no effective way to monitor and prevent such errant behavior. The moral hazard problem may arise also if the principal faces high cost of enforcing the contract subscribed with the agent. A principal facing the moral hazard risk has two options: (a) find a way to align the incentive of the agent with his own, (b) or if unable to do so, restrict access or refuse to provide funding.

The second effect of the access wedge relates to the cost of the financial transaction. Even when there is no principal-agent problem, there may still be a problem of access to finance where the transaction cost involved in the provision of finance exceeds the expected risk-adjusted return. Such a scenario may arise due to inability of financial intermediaries to reduce costs by harnessing economies of scale and scope, such as providing finance to poor households and micro, small and medium enterprises which may be an unprofitable business as a result of high cost per transaction.

Finally, the problem of asymmetric information and transactions costs can generate further dilemma that make the explanation of access to certain groups of the population, e.g. the low income households, very difficult. For example, when an investor decides to initiate lending to a risky group of borrower, it will bear all the costs in case of failure to pay, but when successful, the lender faces fierce competition. Similarly, when a new technology is introduced successfully, it can easily be adopted by competitors, who will not share the research costs. Because of these dilemmas, results of investment in these areas will fall below the social optimum; unless government intervenes to moderate costs and benefits efficiently.

\subsection{Empirical Review}

Salman, Ayo-Oyebiyi and Emenike (2015) examined the influence of financial inclusion dimensions (mobile banking, banking services and banking penetration) on SMEs growth and development in Nigeria. The researchers carried out a survey of 625 Small scale businesses in all the local government areas of Oyo state in south-west Nigeria.. The study covered bakery, block making, fabric making and hairdressing. Linear Regression Analysis was employed to analyse data collected. The result revealed that financial inclusion dimensions (mobile banking, banking services and banking penetration) have positive and significant influence on SMEs growth and development. The study recommends that government should provide capacity building efforts that could lead to well-managed, sustainably financed MSME support mechanisms.

Ibor, Offiong and Mendie (2017) investigated the impact of financial inclusion on the micro, small and medium enterprises (MSMEs) performance in Nigeria. According to them, Nigeria has a sizeable rural poor population with limited access to conventional financial institutions or services. The survey research design method was used in collecting data from respondents. Data were analyzed using the Pearson Chi-square technique. The result reveal that financial inclusion positively and significantly impacted the operations and growth of MSMEs, though distance to financial services access point, infrastructural deficiency remain a serious challenge to effective access to financial services by MSMEs. The study recommends that deliberate efforts should be made to spread access points to more rural areas and improve the infrastructure.

According to Bertram, Nwankwo and Onwuka (2016), financial inclusion is a prerequisite for inclusive economic development in Nigeria. Using the descriptive survey methodology, they employed questionnaires to generate data on financial inclusion from stakeholders such as Banks, Insurance companies, Regulators, and Telecom firms. The study revealed that financial inclusion is a bold step towards inclusive economic development. Accordingly, they concluded that all initiatives that make formal financial services available, accessible and affordable to all segments of the population should be encouraged to achieve inclusive economic development.

Ajinaja and Odeyale (2017) evaluated microfinance activities and the challenge of financial inclusion for SMEs development in Nigeria. The study adopted two separate econometric models for capturing and testing the time series data collected between 2005 and 2015. The first model determined whether financial inclusion improve the financial well-being of low income savers while the second investigated the impact that micro finance has on the performance of small and medium scale enterprises. Findings from the empirical results in model one (1) and two (2) indicated significant relationship between financial inclusion, microfinance, and small business enterprises over the 10 years period of study. The study concludes that financial inclusion will have a positive and significant impact on the development of small and medium scale business if the plan to include everyone works in Nigeria.

Otiato (2016) studied the determinants of financial inclusion among the SMEs in Nairobi City County using the indicators of access, quality and usage of various financial services. The study revealed that the determinants of performance among the SMEs in Nairobi City County included; product/service costs, volume levels traded, profit margins, human resource levels and efficiency levels. The results also identified technological innovations such as MPESA, Mshwari and Agency banking as the most crucial technology factors which played a crucial part in improving their businesses. 
Atueyi, Nkechukwu and Jacobs (2019) examined the effect of financial inclusion on small and medium enterprises in Nigeria from 1981 to 2019. Data used in this study are secondary data sourced from the Central Bank of Nigeria Statistical Bulletin. The variables are on performance of small and medium scale enterprise, commercial bank deposit to rural areas, monetary policy rate, commercial bank loan to rural areas and lending rate. The study employed the Augmented Dickey Fuller (ADF) test for unit root analysis, Johansen cointegration test to establish long run relationship for the variables, and Error Correction Model for data estimation, The findings indicate that commercial bank loan to rural areas has a significant positive effect on small and medium scale enterprise in Nigeria; and that commercial bank deposit to rural areas has a significant positive effect on small and medium scale enterprise in Nigeria. The study concludes that financial inclusion has significant impact on small and medium enterprises in Nigeria. Based on the findings the study recommends that the monetary authority should compel commercial banks to spread its payment machine (ATM, POS) across rural areas to ensure access to financial services. Commercial banks should also reduce the borrowing rate especially for small and medium enterprises to enable them expansion their businesses.

\section{Methodology}

The study employed the ex-post facto research design. The population of the study consists of the five basic aspects of the financial system that are captured in the CBN's Financial Inclusion Strategy 2018 and identified as basis for evaluating the extent of financial inclusion in Nigeria. Secondary data were collected using annual time series data covering 1991 to 2019. The data were collected from the Central Bank of Nigeria (CBN) Statistical Bulletin, 2019 edition. The time framework covered by the study was informed by the period that e-banking transactions started in Nigeria.

This study modified the model employed by Onaolapo (2015) that financial inclusion significantly affects SMEs contribution to sustainable economic growth in Nigeria. The re-modified econometric model is specified below:

$\mathrm{LA}=\mathrm{f}(\mathrm{MK} / \mathrm{TCP}, \mathrm{PA}, \mathrm{IA}, \mathrm{MFA}, \mathrm{EB})$

1

The function can be written as:

$\mathrm{LA}=\alpha+\beta_{1} \mathrm{MKTCP}+\beta_{2} \mathrm{PA}+\beta_{3} \mathrm{IA}+\beta_{4} \mathrm{MFA}+\beta_{5} \mathrm{EBDUM}+\mu_{\mathrm{t}} \ldots \ldots 2$

Where:

$\begin{array}{lll}\text { LA } & = & \begin{array}{l}\text { Loan and Advances to SMEs as \% of total loans } \\ \text { MKTCP }\end{array} \\ \text { PA } & = & \text { Market Capitalization per head } \\ \text { IA } & = & \text { Insurance Account per head } \\ \text { MFA } & = & \text { Micro Finance Account per head } \\ \text { EBDUM } & = & \begin{array}{l}\text { Dummy of E-Banking Transactions where } 0 \text { is period of absence } \\ \text { of E-banking and } 1 \text { for periods of E-banking in Nigeria }\end{array} \\ \alpha_{0} & = & \text { is the intercept (constant) of the regression. } \\ \beta_{1}-\beta_{4} & = & \text { Parameters of the estimated variables } \\ \mu_{\mathrm{t}} & = & \text { error terms }\end{array}$

The model was analyzed using a multiple regression based on Autoregressive Distributive Lag.

4. Results and Discussion

Table 1: Unit root tests using ADF with intercept

\begin{tabular}{|l|l|l|l|l|l|}
\hline & \multicolumn{2}{|c|}{ At Level } & \multicolumn{2}{c|}{ First Difference } & \multirow{2}{*}{ Remark } \\
\hline & t-statistic & p.value & t-statistic & p.value & $1(1)$ \\
\hline LA & -1.4144 & 0.5609 & -7.4713 & 0.0000 & $1(1)$ \\
\hline MKTCP & -0.9022 & 0.7725 & -5.5368 & 0.0001 & $1(1)$ \\
\hline IA & -0.8162 & 0.7989 & -5.3615 & 0.0002 & $1(1)$ \\
\hline MFA & -2.3213 & 0.1728 & -4.3399 & 0.0021 & $1(0)$ \\
\hline EBDUM & -73.247 & 0.0001 & - & - & $1(1)$ \\
\hline
\end{tabular}

The time series variables covered a period of twenty six years spanning 1991 to 2020 (see Appendix 2). The Augmented Dicky Fuller unit root technique was used to determine the stationarity of the variables. The results as shown on Table 1 reveals that natural log of Loans and Advances to the SMEs (LA), market capitalisation per head, (MKTCP), Pension account per head, Insurance account per head (IA) and Dummy of E-banking services in Nigeria (EBDUM) were not stationary in their levels $1(0)$, but became stationary in their first differences, 1(1). This suggests that LA, MKTCP, PA, IA and EBDUM have distinctive long run and short run dynamism, and as such demands separate computation of long and short run effects. However, the result of unit root of Micro Finance Account per head (MFA) is stationary at level, 1(0) and thus can use one result output to explain both short and long run dynamics of its relationship to the dependent variable. 
Table 2: ARDL Bounds Test for long run effect of financial inclusion strategies on access to credit by SMEs in Nigeria

ARDL Bounds Test

Date: 05/07/21 Time: 05:27

Sample: 19942019

Included observations: 26

\begin{tabular}{|l|c|c|}
\hline Test Statistic & Value & $\mathrm{k}$ \\
\hline F-statistic & 58.69623 & 5 \\
\hline Critical Value Bounds & I0 Bound & I1 Bound \\
\hline Significance & 2.62 & 3.79 \\
\hline $5 \%$ & 3.41 & 4.68 \\
\hline $1 \%$ & S
\end{tabular}

The ARDL co-integration technique is thus adopted since the variables that are integrated of different orders comprising I(0) and I(1) (Nkoro \& Uko, 2016: 64). The result of the bound test for long run relationship between financial inclusion strategies and access to MSMEs credit is shown on Table 2. The ARDL result is used to compare the bound critical values with the F-statistics values. The criteria is to reject the null hypothesis "No long-run relationship exists", when the F-statistic is above the upper and lower critical bound values. The computed F-statistics (58.6962) fall outside the lower (2.62) and upper (3.79) bounds at 5\% level of significance. Thus the null hypothesis is rejected and we conclude that long run relationship exists between financial inclusion variables and access to credit for MSMEs in Nigeria.

Table 3: Long run dynamics effects and model

\begin{tabular}{|c|c|c|c|c|}
\hline \multicolumn{4}{|c|}{ ARDL Cointegrating And Long Run Form } & \\
\hline \multicolumn{4}{|c|}{ Dependent Variable: LNLA } & \\
\hline \multicolumn{4}{|c|}{ Selected Model: ARDL $(3,3,3,3,3,3)$} & \\
\hline \multicolumn{3}{|c|}{ Date: 05/07/21 Time: 05:30 } & & \\
\hline \multicolumn{3}{|c|}{ Sample: 19912019} & & \\
\hline \multicolumn{3}{|c|}{ Included observations: 26} & & \\
\hline \multicolumn{5}{|c|}{ Cointegrating Form } \\
\hline Variable & Coefficient & Std. Error & t-Statistic & Prob. \\
\hline CointEq(-1) & -11.366638 & 2.289585 & -4.964498 & 0.0383 \\
\hline \multicolumn{5}{|c|}{ Cointeq $=$ LNLA $-(3.7945 *$ MKTCP $+0.2980 *$ PA $-0.2146 *$ IA $-1.6535 *$ MFA $+0.2865 *$ EBDUM +6.6912$)$} \\
\hline \multicolumn{5}{|c|}{ Long Run Coefficients } \\
\hline Variable & Coefficient & Std. Error & t-Statistic & Prob. \\
\hline MKTCP & 3.794464 & 0.157920 & 24.027775 & 0.0017 \\
\hline PA & 0.298030 & 0.052427 & 5.684685 & 0.0296 \\
\hline IA & -0.214568 & 0.018552 & -11.565508 & 0.0074 \\
\hline MFA & -1.653477 & 0.060696 & -27.242136 & 0.0013 \\
\hline EBDUM & 0.286461 & 0.006581 & 43.527306 & 0.0005 \\
\hline $\mathrm{C}$ & 6.691241 & 0.032569 & 205.451189 & 0.0000 \\
\hline
\end{tabular}

The value of the co-integrating equation at lag one $\{\mathrm{CointEq}(-1)\}$ explains the propensity to achieve a long run and sustainable loan and availability of funds to the MSMEs with a sustained financial inclusion strategy. The coefficient -11.3666 is well signed and has a p.value (0.0383) less than 0.05 level of significance; an indication that financial inclusion strategies in Nigeria can sustain the growth of the MSME financing. The coefficients of long run relationships of financial inclusion variables (MKTCP, PA, IA, MFA and EBDUM) and Credit to MSME revealed a supportive evidence. All the variables showed a statistically significant long run effects (at 5\%) on credit to MSMEs. The outcome indicated that MKTCP (3.7944, p. 0.0017), PA (0.2980, p. $0.0296)$, and EBDUM (0.2865, p. 0.0005) have positive effects while IA (-0.2146, p. 0.0074) and MFA (-1.6535, p. 0.0013) showed adverse impact on credit to MSMEs. These indicate that financial inclusion is a veritable long term strategic plan for developing the micro and small business enterprises in Nigerian economy. 
Table 4: Short run dynamic relationship between financial inclusion and access to credit (Loans and advances) for SMEs in Nigeria

\begin{tabular}{|c|c|c|c|c|}
\hline \multicolumn{3}{|c|}{ Dependent Variable: LNLA } & & \\
\hline \multicolumn{3}{|c|}{ Method: ARDL } & & \\
\hline \multicolumn{5}{|c|}{ Date: 05/07/21 Time: 05:25 } \\
\hline \multicolumn{5}{|c|}{ Sample (adjusted): 19942019} \\
\hline \multicolumn{5}{|c|}{ Included observations: 26 after adjustments } \\
\hline \multicolumn{5}{|c|}{ Maximum dependent lags: 3 (Automatic selection) } \\
\hline \multicolumn{5}{|c|}{ Model selection method: Akaike info criterion (AIC) } \\
\hline \multicolumn{5}{|c|}{ Dynamic regressors (3 lags, automatic): MKTCP PA IA MFA EBDUM } \\
\hline \multicolumn{5}{|c|}{ Fixed regressors: $\mathrm{C}$} \\
\hline \multicolumn{5}{|c|}{ Number of models evalulated: 3072} \\
\hline \multicolumn{5}{|c|}{ Selected Model: ARDL(3, 3, 3, 3, 3, 3) } \\
\hline Variable & Coefficient & Std. Error & t-Statistic & Prob. ${ }^{*}$ \\
\hline $\operatorname{LNLA}(-1)$ & -1.113900 & 0.164202 & -6.783696 & 0.0210 \\
\hline LNLA(-2) & -0.363895 & 0.517650 & -0.702975 & 0.5549 \\
\hline LNLA(-3) & -8.888844 & 1.940267 & -4.581247 & 0.0445 \\
\hline MKTCP & -7.911738 & 3.294524 & -2.401481 & 0.1383 \\
\hline MKTCP(-1) & 27.44079 & 5.118503 & 5.361095 & 0.0331 \\
\hline MKTCP $(-2)$ & 20.30241 & 6.244240 & 3.251381 & 0.0830 \\
\hline $\operatorname{MKTCP}(-3)$ & 3.298850 & 1.525500 & 2.162471 & 0.1631 \\
\hline PA & -0.093691 & 0.090657 & -1.033462 & 0.4100 \\
\hline PA(-1) & 2.692330 & 0.712807 & 3.777080 & 0.0535 \\
\hline PA(-2) & 0.512079 & 0.279028 & 1.835227 & 0.2079 \\
\hline PA(-3) & 0.276878 & 0.313249 & 0.883892 & 0.4700 \\
\hline IA & 0.979220 & 0.194767 & 5.027657 & 0.0374 \\
\hline $\mathrm{IA}(-1)$ & 0.552426 & 0.346637 & 1.593670 & 0.2520 \\
\hline $\mathrm{IA}(-2)$ & 0.838845 & 0.391730 & 2.141383 & 0.1656 \\
\hline $\operatorname{IA}(-3)$ & -4.809406 & 1.178051 & -4.082512 & 0.0551 \\
\hline MFA & -1.042766 & 0.786115 & -1.326479 & 0.3159 \\
\hline MFA(-1) & -25.33975 & 5.463576 & -4.637942 & 0.0435 \\
\hline $\operatorname{MFA}(-2)$ & 9.001364 & 2.053465 & 4.383500 & 0.0483 \\
\hline $\operatorname{MFA}(-3)$ & -1.413326 & 0.342382 & -4.127919 & 0.0540 \\
\hline EBDUM & 3.626315 & 0.519029 & 6.986725 & 0.0199 \\
\hline EBDUM(-1) & -5.123356 & 0.944272 & -5.425721 & 0.0323 \\
\hline $\operatorname{EBDUM}(-2)$ & 4.525620 & 0.999726 & 4.526860 & 0.0455 \\
\hline EBDUM(-3) & 0.227524 & 0.072066 & 3.157142 & 0.0874 \\
\hline $\mathrm{C}$ & 76.05691 & 14.98715 & 5.074809 & 0.0367 \\
\hline R-squared & 0.999629 & \multicolumn{2}{|c|}{ Mean dependent var } & 6.715950 \\
\hline Adjusted R-squared & 0.995366 & \multicolumn{2}{|c|}{ S.D. dependent var } & 0.278930 \\
\hline S.E. of regression & 0.018987 & \multicolumn{2}{|c|}{ Akaike info criterion } & -5.808920 \\
\hline Sum squared resid & 0.000721 & \multicolumn{2}{|c|}{ Schwarz criterion } & -4.647600 \\
\hline Log likelihood & 99.51596 & \multicolumn{2}{|c|}{ Hannan-Quinn criter. } & -5.474502 \\
\hline F-statistic & 234.4925 & \multicolumn{2}{|c|}{ Durbin-Watson stat } & 3.240112 \\
\hline Prob(F-statistic) & 0.004255 & & & \\
\hline
\end{tabular}

The coefficient of determination $\left(\mathrm{R}^{2}\right)$ is 0.9996 with an F-statistic (234.4925) significant at 0.0043. This result explains that financial inclusion strategies (market capitalisation, Pension account, Insurance account, microfinance account and e-banking) have significant effect on credit to MSMEs in Nigeria. It equally connotes that financial inclusion strategies explains about $99 \%$ of credit grants to MSMEs in Nigeria. Hence financial inclusion is the bedrock of investment and access to funds by the MSMEs in Nigeria.

The endogenous effect of previous access to loan and advances (LA) revealed a negative coefficient as at lag 1 (-0.6855), lags (-0.3639), and lag 3 (-8.8888), with p.values less than 0.05 level of significance lags 1 and 3 , respectively. Credit to MSMEs is a statistically significant endogenous variable in explaining financial inclusion strategies in Nigeria.

The results on Table 2 revealed that activities in the capital market (MKTC) and pension accounts (PA) at lag 1 have positive and significant effects on credit to MSMEs (LA) in Nigeria. The lag 1 coefficients of market capitalisation and pensions account are MKTCP $(27.4408, \mathrm{p}<0.0331)$ and PA $(2.6923, \mathrm{p} 0.0535)$. Increasing 
activities in the capital market and pension accounts significantly enhances the propensity for MSME funding. The capital market and the pension funds in Nigeria have contributed largely to financing entrepreneurship development of the micro and start-up businesses in Nigeria.

Moreover, the insurance accounts (IA), micro finance account (MFA) and e-banking innovations (EBDUM) creates unstable significant effects on credit to MSMEs in Nigeria. The coefficients of IA, MFA and EBDUM gyrates between positive and negative influence on flow of credits to the MSMEs. This is evident from the results on Table 2. The coefficient of IA shows positive and significant (Coef. 0.9792, p. 0.0374) at level but negative and significant effects at lag 3 (coef. -4.8094, p. 0.0551). For the MFA, the coefficients show a negative and significant effects at lag 1 (coef. -25.3398 , p. 0.0435) and lag 3, (coef. -1.4133 , p. 0.0540) respectively. However, at lag 2, MFA indicated a positive and significant effect on credit to SMEs (coef. 9.0014, p. 0.0483). Similarly, the coefficients of e-banking had positive and significant effects at level (coef. 3.6263, p. 0.0199), and lag 2 (4.5256, p. 0.0455) but negative and significant effect at lag $1(-5.1234$, p. 0.0323$)$.

\section{Conclusion and Recommendations}

The broad conclusion from the study is that financial inclusion strategies have long run implication for Nigeria's MSME's financing. Economic policies to reposition the role of SMEs and micro businesses in driving investments and economic growth in Nigeria should take recourse to boosting the financial market to accommodate the micro sectors. However, the activities of the insurance, microfinance and e-banking services demand very effective and drastic actions and short term periodic reviews to align the MSMEs with the demands of sustainable growth and development. Some of the demands include:

1 Massive investment in the information technology architecture to provide and sustain seamless internet, mobile and digital banking to avoid systemic break downs to guarantee accessibility and confidence in the system.

2 The cost of assessing e-banking in form of data charges should be borne by the financial service providers to reduce the financial burden on the low income population to facilitate financial inclusion and effectiveness of monetary policy transmission.

3 The $\mathrm{CBN}$ and the conventional banks should work in collaboration with the educational sector to design and implement mass financial literacy programmes to empower the masses for full scale digital banking.

4 All SMEs should be required by law to employ a category of qualified and experienced professionals or employ the services of highly qualified consultants to improve their accounting, managerial and financial management capacity as a pre-requisite for participation in the micro-finance scheme.

5 Both the microfinance operators and its major borrowers should be made to consistently apply professionally prescribed accounting standards and independent audit requirements and also to go through a regular process of strengthening of management and upgrading the quality of its credit appraisal and monitoring staff to ensure satisfactory performance of the business and timely repayment of the loans.

6 Increasing use of computer-techniques for management information communication and a variety of routine operations e.g. payment for creditors and shareholders, loan disbursement, client obligations and payments, personnel and pay actions, internal accounts, financial protection on behalf of clients and comprehensive financial projection of the SMEs will greatly improve efficiency.

\section{References}

Abusomwan, S.O, Liberty N. \& Arodoye, L. N. (2017). Small and medium enterprises' financing and dynamics of gross fixed capital formation: evidence from Nigeria. International Journal of Business Finance, 15(1), 90-99.

Aduda, J., \& Kalunda, E. (2016). Financial inclusion and financial sector stability with reference To Kenya: A Review of Literature. Journal of Applied Finance \& Banking, 2 (9), 110- 111.

Ajinaja, T. \& Odeyale, A. J. (2017). Microfinance and the Challenge of Financial Inclusion for SMEs' Development in Nigeria. Journal of Business and Management, 19(2), 11-18.

Amadasu, D. (2017). Effect of Rural Bank Deposits on SMEs in Nigeria. International Multi-Disciplinary Journal, Ethiopia 5(6) $11-18$.

Atueyi, C. L., Nkechukwu, G.C. \& Jacobs C. J. (2019). Effect of Financial Inclusion on Small and Medium Scale Enterprise in Nigeria. International Journal of Management and Marketing Systems, 3(5), 1-17

Berk, T. \& Levine, R (2005). Legal Institutions and Financial Development, cited in Menard, C \& Shirley, M (Eds) Handbook of New Institutional Economics, Academic Publication Khuwa.

Berk, T.A., Demiraguckunt \& Levine (2004). Finance Inequality and Poverty: Cross Country Evidence Policy Research Working Paper No 3338, World Bank. Journal of Economic Growth, 12(1) 27 - 49.

Bertram, O. A., Nwankwo, S. N. P. \& Onwuka, I. O. (2016). Full financial inclusion: A pre- requisite for inclusive economic development in Nigeria. Advances in Social Sciences Research Journal, 3(9), 65 - 78. 
Caskey, J.C., Duran, R \& Solo, T.M. (2006). THE Urban Unbanked in Mexico and the United States. Policy Research Working Paper, No. 1835 Working Paper, World Bank, Washington DC.

Central Bank of Nigeria (2013). CBN Statistical Bulletin 2013, volume 24, Abuja.

Central Bank of Nigeria (2014). CBN Statistical Bulletin 2014, volume 25, Abuja.

Central Bank of Nigeria (2018). National Financial Inclusion Strategy. Abuja: CBN.

Centre for Financial Inclusion (2013). Financial Inclusion: How best can it be strengthened? Business World Intelligence. www.businessworld.com.

Claessens, S, (2006). Access to Financial Series: A Review of the Issues and Public Policy Objectives. Oxford Journal 21, $207-240$.

Cressy, R. (2002). Introduction - Funding Gaps Economic Journal, 112(177) F16.

De la Torre, A., Gozzi, J. G. \& Schmukler, S. (2007). Innovative Experiences in Access to Financial Policy Research Working Paper, World Bank, Washington DC.

Demirguc-kunt, A. \& Levine, R. (2004). Finance, Inequality, and Poverty: Cross-Country Evidence, NBER Working Paper, W10979.

Demirguc-Kunt, A. \& Levine, R. (2007). Finance and Economic Opportunity. Policy Research Working Paper 4468. World Bank, Washington, D.C.

Drypas, P. \& Robinson, J. (2009). Savings Constructs and Macro-Enterprise Development: Evidence from a field experience in Kenya. NBER Working Paper No. 14603, National Bureau for Economic Research Cambridge, M.A.

Honohan, P. (2004). Financial development, growth and poverty: How close are the links? Development Research Group and Financial Sector Operations and Policy Department. The World Bank.

Ibenta, S. N. (2000). Nigerian Money and Capital Markets: Theory \& Practice. Lagos: Afribase Publishers.

Ibenta, S.N.O. \& Amana, S.A. (2010). Microfinance Institution and Poverty Reduction in Nigeria, Journal of Business and Management, 4(2), $56-65$.

Ibor, B.I., Offiong, A.I. \& Mendie, E.S. (2017). Financial inclusion and performance of micro, small and medium scale enterprises in Nigeria. International Journal of Research - GRANTHAALAYAH, 5(3),

Imoughele, L. E. \& Ismaila, M. (2014). The impact of rural bank loan on the growth of small and medium scale enterprises: An econometric evidence from Nigeria. Journal of Educational Policy and Entrepreneurial Research, 1, (2), 251-261.

Mbam, B. N. (2012). Effects of rural banking deposit on the small and medium scale enterprises in Ebonyi State. Journal of Agricultural research and development, 2(1), 031-036.

Nkoro, E., Uko, A. K. (2016). Autoregressive Distributed Lag (ARDL) cointegration technique: application and interpretation. Journal of Statistical and Econometric Methods, 5(4), 63-91.

Nwanko, O. \& Nwanko, N.O. (2014). Sustainability of financial inclusion to rural dwellers in Nigeria: Problems and Way Forward. Research Journal of Finance and Accounting, 5(5), 24-31.

Nwosa, P.I. \& Oseni, I.O. (2013).The impact of bank loans to SMEs on manufacturing output in Nigeria. Journal of Social and Development Sciences, 4(5), 212-217.

Onaolapo, A. R. (2015). Effects of financial inclusion on the economic growth of Nigeria. International Journal of Business and Management Review, 3(8), 11-28.

OECD, (2006). The SME Financing Gap - Volume I: Theory and Evidence. OECD Press.

Otiato, E.H. (2016). Determinants of financial inclusion and performance of small and medium enterprises in Nairobi City County. International Journal of Finance and Accounting 3(4) 62 - 78.

Owolabi, O.A. \& Nasiru, A. (2017). Deposit money bank credit to small and medium enterprises socio-economic performance and economic growth in Nigeria. Journal of Development and Sustainability, 6 (10), 14001417.

Peachey, S., \& Roe, A. (2004). Access to Finance. A Study for the World Savings Banks Institute, Oxford.

Salman, A. Y., Ayo-Oyebiyi, G.T \& Emenike, O. A. (2015). Influence of financial inclusion on small and medium enterprises growth and development In Nigeria. International Journal in Management and Social Science 3(4),

Schiffer, M. \& Weder, B. (2001). Firm Size and Business Environment: "World-wide Survey Results" Discussion Paper 43, IFC Washington DC.

Stiglitz, G.E. \& Weiss, A. (1981) Credit Ration in Market with Imperfect Information. American Economic Review 71(3) 393 - 410.

Uduakobong, I. (2014). Money Supply and SMEs in Nigeria: A Econometric Analysis. Journal of Economics and Sustainable Development 5(1), $112-119$.

Van Horne J.V. \& Wachowicz J.M. (2005). Fundamental of Financial Management. ET Prentice, UK.

World Bank (2013, July). Retrieved from World Bank website: http://go.worldbank.org/IZQKQHR49. 
Appendix 1: Raw data for value of market capitalization, number of pension, insurance, microfinance, and commercial bank accounts.

\begin{tabular}{|c|c|c|c|c|c|c|}
\hline Year & Population & $\begin{array}{l}\text { MCAP (Naira } \\
\text { Billion) }\end{array}$ & PEN & INS & $\mathrm{MIC}$ & $\mathrm{CBA}$ \\
\hline 1991 & $97,667,632.00$ & 236.52 & 0 & $976,676.32$ & $1,479,812.61$ & $1,975,816.20$ \\
\hline 1992 & $100,161,710.00$ & 311.5 & 0 & $1,051,697.96$ & $249,779.83$ & $2,278,678.90$ \\
\hline 1993 & $102,700,753.00$ & 462.51 & 0 & $1,078,357.91$ & $116,838.10$ & $2,421,683.76$ \\
\hline 1994 & $105,293,700.00$ & 629.67 & 0 & $1,084,525.11$ & $108,550.21$ & $2,530,207.61$ \\
\hline 1995 & $107,948,335.00$ & $1,671.17$ & 0 & $971,535.02$ & $79,666.67$ & $2,556,216.57$ \\
\hline 1996 & $110,668,794.00$ & $2,582.48$ & 0 & $996,019.15$ & $80,898.24$ & $2,663,797.87$ \\
\hline 1997 & $113,457,663.00$ & $2,484.63$ & 0 & $941,698.60$ & $111,780.95$ & $2,730,925.95$ \\
\hline 1998 & $116,319,759.00$ & $2,257.57$ & 0 & $663,022.63$ & $114,600.75$ & $2,541,586.73$ \\
\hline 1999 & $119,260,063.00$ & $2,515.51$ & 0 & $679,782.36$ & $117,613.47$ & $2,605,832.38$ \\
\hline 2000 & $122,283,850.00$ & $3,862.33$ & 0 & $697,017.95$ & $138,801.19$ & $2,681,684.83$ \\
\hline 2001 & $125,394,046.00$ & $5,283.34$ & 0 & $714,746.06$ & $167,863.52$ & $2,749,891.43$ \\
\hline 2002 & $128,596,076.00$ & $5,948.08$ & 0 & $732,997.63$ & $167,225.07$ & $3,870,741.89$ \\
\hline 2003 & $131,900,631.00$ & $10,305.49$ & 0 & $751,833.60$ & $170,414.25$ & $4,282,813.49$ \\
\hline 2004 & $135,320,422.00$ & $15,611.10$ & 0 & $1,393,800.35$ & $179,708.40$ & $4,725,389.14$ \\
\hline 2005 & $138,865,016.00$ & $20,874.95$ & 0 & $1,430,309.66$ & $183,441.24$ & $1,362,126.94$ \\
\hline 2006 & $142,538,308.00$ & $36,015.68$ & $299,330.45$ & $1,468,144.57$ & $190,051.08$ & $4,608,263.50$ \\
\hline 2007 & $146,339,977.00$ & $90,022.24$ & $321,947.95$ & $1,126,817.82$ & $206,403.35$ & $6,146,279.03$ \\
\hline 2008 & $150,269,623.00$ & $63,438.13$ & $571,024.57$ & $811,455.96$ & $216,215.28$ & $7,441,351.73$ \\
\hline 2009 & $154,324,933.00$ & $45,554.53$ & $586,434.75$ & $756,192.17$ & $186,382.77$ & $8,389,103.36$ \\
\hline 2010 & $158,503,197.00$ & $62,518.56$ & $554,761.19$ & $776,665.67$ & $197,881.64$ & $9,207,450.71$ \\
\hline 2011 & $162,805,071.00$ & $63,114.28$ & $569,817.75$ & $993,110.93$ & $198,300.94$ & $8,879,388.57$ \\
\hline 2012 & $167,228,767.00$ & $88,507.16$ & $518,409.18$ & $1,003,372.60$ & $189,387.05$ & $9,304,608.60$ \\
\hline 2013 & $171,765,769.00$ & $111,065.05$ & $635,533.35$ & $910,358.58$ & $208,200.93$ & $9,685,871.71$ \\
\hline 2014 & $176,404,902.00$ & $95,661.19$ & $564,495.69$ & $846,743.53$ & $197,985.30$ & $9,748,134.88$ \\
\hline 2015 & $181,137,448.00$ & $93,870.11$ & $579,639.83$ & $887,573.50$ & $191,073.26$ & $9,908,218.41$ \\
\hline 2016 & $185,960,289.00$ & $87,038.63$ & $595,072.92$ & $911,205.42$ & $188,409.61$ & $10,357,988.10$ \\
\hline 2017 & $190,873,311.00$ & $110,695.92$ & $610,794.60$ & $1,145,239.87$ & $193,387.35$ & $10,906,500.99$ \\
\hline 2018 & $195,874,740.00$ & $111,826.75$ & $607,211.69$ & $920,611.28$ & $198,454.65$ & $10,383,319.97$ \\
\hline 2019 & $197,874,141.00$ & $112,821.75$ & $611,221.62$ & $950,621.25$ & $208,254.65$ & $11,383,319.93$ \\
\hline
\end{tabular}


Appendix 2: Transformed data for Financial inclusion and MSMEs credit variables

\begin{tabular}{|c|c|c|c|c|c|c|}
\hline Date & LNLA & МKТСР & PA & IA & MFA & EBDUM \\
\hline 1991 & 6.2957 & 0.0002 & 0.3 & 1 & 1.5152 & 0 \\
\hline 1992 & 6.3577 & 0.0003 & 0.06 & 1.05 & 0.2494 & 0 \\
\hline 1993 & 6.3841 & 0.0005 & 0.32 & 1.05 & 0.1138 & 0 \\
\hline 1994 & 6.4032 & 0.0006 & 0.32 & 1.03 & 0.1031 & 0 \\
\hline 1995 & 6.4076 & 0.0015 & 0.12 & 0.9 & 0.0738 & 0 \\
\hline 1996 & 6.4255 & 0.0023 & 0.34 & 0.9 & 0.0731 & 0 \\
\hline 1997 & 6.4363 & 0.0022 & 0.43 & 0.83 & 0.0985 & 0 \\
\hline 1998 & 6.4051 & 0.0019 & 0.43 & 0.57 & 0.0985 & 0 \\
\hline 1999 & 6.4159 & 0.0021 & 0.43 & 0.57 & 0.0986 & 0 \\
\hline 2000 & 6.4284 & 0.0032 & 0.02 & 0.57 & 0.1135 & 0 \\
\hline 2001 & 6.4393 & 0.0042 & 0.32 & 0.57 & 0.1339 & 0 \\
\hline 2002 & 6.5878 & 0.0046 & 0.32 & 0.57 & 0.13 & 0 \\
\hline 2003 & 6.6317 & 0.0078 & 0.21 & 0.57 & 0.1292 & 0 \\
\hline 2004 & 6.6744 & 0.0115 & 0.43 & 1.03 & 0.1328 & 0 \\
\hline 2005 & 6.1342 & 0.015 & 0.32 & 1.03 & 0.1321 & 0 \\
\hline 2006 & 6.6635 & 0.0253 & 0.21 & 1.03 & 0.1333 & 0 \\
\hline 2007 & 6.7886 & 0.0615 & 0.22 & 0.77 & 0.141 & 1 \\
\hline 2008 & 6.8717 & 0.0422 & 0.38 & 0.54 & 0.1439 & 1 \\
\hline 2009 & 6.9237 & 0.0295 & 0.38 & 0.49 & 0.1208 & 1 \\
\hline 2010 & 6.9641 & 0.0394 & 0.35 & 0.49 & 0.1248 & 1 \\
\hline 2011 & 6.9484 & 0.0388 & 0.35 & 0.61 & 0.1218 & 1 \\
\hline 2012 & 6.9687 & 0.0529 & 0.31 & 0.6 & 0.1133 & 1 \\
\hline 2013 & 6.9861 & 0.0647 & 0.37 & 0.53 & 0.1212 & 1 \\
\hline 2014 & 6.9889 & 0.0542 & 0.32 & 0.48 & 0.1122 & 1 \\
\hline 2015 & 6.996 & 0.0518 & 0.32 & 0.49 & 0.1055 & 1 \\
\hline 2016 & 7.0153 & 0.0468 & 0.32 & 0.49 & 0.1013 & 1 \\
\hline 2017 & 7.0377 & 0.058 & 0.32 & 0.6 & 0.1013 & 1 \\
\hline 2018 & 7.0163 & 0.0571 & 0.31 & 0.47 & 0.1013 & 1 \\
\hline 2019 & 7.0563 & 0.057 & 0.3089 & 0.4804 & 0.1052 & 1 \\
\hline
\end{tabular}

Key: LA (Loan and Advances to SMEs as of total loans), MKTCP (Market Capitalization per head), PA (Pension Account per head), IA (Insurance Account per head), MFA (Micro Finance Account per head) and EBDUM (Dummy of E-Banking Transactions where 0 is period of absence of E-banking and 1 for periods of Ebanking in Nigeria) 